\title{
Factory-Built Housing: Statutory Solutions
}

American housing policy is characterized by a twofold failure. The first is the inability to provide adequate housing for low- and moderateincome families. The most recent estimates indicate that housing costs have risen to a level that puts unsubsidized housing beyond the reach of seventy per cent of American families. ${ }^{1}$ Moreover, the present rate of housing starts must double in order to replace existing substandard housing and to provide for new families entering the market. ${ }^{2}$

The second failure is the perpetuation of artificial restrictions in the suburban housing market which have effectively excluded lower income groups from these communities. ${ }^{3}$ The residential segregation which has resulted from this policy has frequently developed along racial lines. ${ }^{4}$ This imprisonment of the poor within the inner city has significantly frustrated national efforts toward social equality. ${ }^{5}$

A partial solution to both aspects of the current housing crisis may lie in the cost reductions made possible through the use of new materials and mass production methods. Plastic pipe, fiberglass fixtures, and plastic baseboards, as well as pre-assembled plumbing and electrical systems, reduce required skill levels and offer the potential for major

1 Frelich \& Seidel, Recent Trends in Flousing Law: Prologue to the 70's, 2 URBAN LAw. $1,3-4$ (1970).

2 Id. at 3. For a detailed analysis of American housing needs, see generally NationaL Comm'n on Urban Problems, Building the American City, H.R. Doc. No. 91-34, 91st Cong., 1st Sess. 66-93 (1968) [hereinafter cited as Dovglas REPORT].

3 NATIONAl Advisory CoMm'n on CivII Disorders, Report 474 (1968). Racial segregation is only one aspect of the problem. Equally significant is the high cost of housing which effectively segregates along economic lines. "Even if new housing were made available on an open-occupancy basis, economic barriers . . . would exclude most Negroes." G. GRIER \& E. GRIER, Equality AND Beyond 84 (1966). Restrictive building practices play an important part in maintaining the high price levels of the American housing market. See generally DOUGLAS REPORT, supra note 2, at 465-75.

4 G. GRIER \& E. GRIER, supra note 3, at 17-25.

5 "Segregation in housing makes desegregation in many other areas of society much more diffcult to attain than it otherwise might be-in education (where it is almost impossible despite 'busing' programs and similar arrangements); in many types of public facilities; and in employment. By impeding the efforts of Negroes to obtain equal preparation for work and life, and by hampering America's two chief racial groups from achieving a secure relationship based upon mutual understanding and respect, residential segregation thus perpetuates the social and psychological barriers that complete the vicious circle." G. GRIER \& E. GRIER, supra note 3, at 84. "Home ownership . . would provide many low income families with a tangible stake in society for the first time." Namonst ADVISORY COMM'N ON Crvil. Disorders, supra note 3, at 477. 
increases in output coupled with decreases in cost to the consumer. ${ }^{6}$ The close relationship between high housing costs and the present pattern of residential segregation ${ }^{7}$ indicates that significant reductions in construction expense may have several important effects. Not only will mass production methods provide adequate housing for a greater proportion of American families, but they also will make possible the integration of economic and social groups into suburban communities where the high cost of home ownership has previously prohibited entry.

However, opportunities implicit in the juxtaposition of new building techniques and vacant suburban land are often frustrated by $\mathrm{mu}$ nicipal building codes. The municipal code, which defines the allowable materials and construction processes within a particular area, is determinative of the process of American home building on two levels. First, the substantive requirements of archaic building codes exclude the new materials associated with manufactured housing; ${ }^{8}$ second, the variety which exists among the thousands of separate codes precludes the use of new mass production techniques. ${ }^{9}$ Moreover, the power of municipalities to determine the cost of new housing is an effective mechanism for segregating disadvantaged groups from the closed communities of suburban areas. ${ }^{10}$

63 U.S. DEP'T of Housing and Urban Development, IN-Cities Experimental Housing Research and Developarent Project: Phase I Compostte Report II-1, -3 (1969). While in Europe "manufactured housing systems have established themselves and are sharing a good portion of the housing market," there has been an actual retrogression in the United States since World War II. W. ALONSO, S. HAssid \& W. SMITH, INFORMation on and Evaluations of Innovations in Housing Design and Construction Techniques as Applied to Low Cost Housing 34 (1969). See also G. Beyer, Housing ANd Society 515 (1965) and DOUGLAS REPORT, supra note 2, at 431-50.

7 See note 3 supra.

8 "[C] $]$ odes have a pervasive influence on building and are crucial regulators in the evolution of building technology." Wright, Performance Criteria in Building, 224 Screntific AMerican, Mar., 1971, at 18. "On a component level, the morass of building codes ... have been instrumental in blocking adoption of technological advances which could contribute to lowering costs." Fisher, Low Cost Housing Systems, 2 URBan LAw. 146, 159 (1970). See also Advisory CoMm'N ON INTERgovernMENTAL RELATIONS, BuILDING CODES: A PROGRAM FOR INTERGOVERNMENTAL REForM 81 (1966): "Too many building codes contain unnecessarily high standards, prevent the use of economical methods and materials in building, and include provisions extraneous to the basic purposes and objectives of building controls."

9 See G. BEYER, supra note 6, at 497 . For some indication of the diversity of code regulations with respect to specific practices, see A. MANvEL, LOcAL LAND AND BUILDING REgulation 3, $11-13$ (1968). See also Advisory COMM'N ON INTERgovernmental, RELATIONS, supra note 8, at 81: "Obsolete code requirements, unnecessary diversity of such requirements among local jurisdictions, and inadequate administration and enforcement, taken together tend to place unjustified burdens on the technology and economics of building."

10 See G. BEYER, supra note 6, at 219; Advisory COMM'N ON INTERGovernMENTAL ReIATHONs, supra note 8 , at 7 . 
Despite its potential for abuse, the municipal building code finds vigorous support at the local level, and attempts at reform are not likely to succeed. Some factions within the financing industry have strongly opposed new housing techniques. ${ }^{11}$ The elimination of the interim financing expense that is accomplished by mass-produced housing could result in a reduction of almost ten per cent in financing costs. ${ }^{12}$ As one commentator explained, "[T] over of the modular technique to more highly priced conventional housing."13 The most powerful opponents of mass production, however, are the craft unions. Pro-automation statements from their national leadership have failed to prevent local craft union resistance to changes which might reduce the number of skilled jobs. ${ }^{14}$ According to the Department of Housing and Urban Development, "[O]ff-site performance of union tasks by non-union labor directly threatens the position of the union and its relationship to the entire construction process." 15 As a result, unions have become involved in the creation and perpetuation of building codes, ${ }^{16}$ and their viewpoint is frequently incorporated into the enforcement process through building inspectors sympathetic to organized labor. ${ }^{17}$ Furthermore, local craft unions are apt to receive strong reinforcement from the materials industries that are closely linked to traditional building processes. ${ }^{18}$ The influence of the unions is manifested by their role in effectively restricting the growth of factory-built housing even in urban areas, where the demand for low-cost housing is greatest. ${ }^{19}$

When the development of low-cost housing systems is so successfully opposed by organized interests in the cities, little code reform can be

11 ADvisory COMM'N on INTERGovernmental RELATIONS, supra note 8, at 7. This opposition evidences a competitive struggle within the financing industry itself. Housing produced by traditional methods is financed largely by savings and loan institutions which are limited by statute to making long-term loans on security of real estate. On the other hand, sales finance companies have garnered much of the burgeoning mobile home market. Thus, the introduction of new housing technology has the effect of reallocating the home financing market and triggers automatic opposition by the institutions detrimentally affected.

12 Fisher, supra note 8, at 156.

$13 I d$.

14 Id. at 164. See also Douglas REPORT, supra note 2, at 465-75.

152 U.S. DEP'T of Housing and URBan Development, In-Cities Experimental Housing Researce and Development Project: Phase I Composite Report III-74 (1969).

$16 I d$.

17 Note, Suburban Zoning Ordinances and Building Codes: Their Effect on Low and Moderate Income Housing, 45 NOTRE DAME LAw. 123, 133 (1969).

18 Advisory COMM'N ON INTERgOVERNMENTAL RELATIONS, supra note 8, at 7; DOUGLAS REPORT, supra note 2 , at 467.

19 As late as 1968, Chicago alone had managed to provide even a limited factory-built housing development, and this was achieved only after significant concessions to the unions. Fisher, supra note 8, at 153, 164. 
expected in the suburbs. In addition to the restricting forces which are operative in urban areas, the suburban dwellers resist any influx of low-income groups. Provoked by fears of antisocial behavior and educational deterioration, ${ }^{20}$ communities characteristically respond to low-cost housing by rezoning and by oppressively enforcing building regulations. ${ }^{21}$ As one report concluded, "The problem of community opposition at desirable sites ... shows little hope of being overcome now or in the future."22

In the face of this powerful opposition, the federal government has relied on an incentive approach to encourage the alteration of building codes and the development of modern techniques of home construction. The most recent program is Operation Breakthrough. ${ }^{23}$ Under this program, a number of communities have accepted prototype housing developments through which the government hopes to demonstrate the feasibility of new construction methods. ${ }^{24}$ This incentive approach to housing reform is not new. In a series of legislative enactments reaching back to 1949, the federal government has attempted to use housing money as a stimulus for code reform. ${ }^{25}$ Furthermore, the President's Task Force on Housing has urged HUD to use eligibility requirements for participation in federal housing and community assistance programs to develop a national certification program for factory-built housing. ${ }^{26}$

The use of federal money as an incentive for building code reform is nonetheless subject to severe limitations. While cities are becoming increasingly dependent on federal housing aid, suburban communities are usually able to forego contingent grants which contain unattractive compliance requirements. Although suggestions have been made to expand the contingent grants to areas other than housing, ${ }^{27}$ success would be dependent on a continuous supply of money in order to "buy

20 Id. at 172.

21 Id. at 164 .

22 G. Greer \& E. Greer, Privately Developed Interracial Housing: An Analysis of EXPERIENCE 29 (1960).

23 Operation Breakthrough, launched in May, 1969, is an effort to channel sophisticated technological, legal, and financial mechanisms into the mainstream of housing production. "It is directed at government and private constraints which effect the quantity and quality of housing production and environment." Burstein, $A$ Lawyer's View of Operation Breakthrough, 2 URBAN LAw. 137 (1970).

24 Id. at 141.

25 G. BEYER, supra note 6 , at 468 . For a survey of federal aid program requirements affecting building construction and codes, see ADVISORY COMM'N ON INTERGOVERNMENTAL RELATIONS, supra note 8 , at 37-38.

26 President's TAsk Force on Low Income Housing, Toward Better Housing for Low INCOME FAMILIES 6 (1970).

27 Fisher, supra note 8 , at 165 . 
in" to each suburban community. Also, there are indications that attempts to expand the number and kinds of contingent grants may be politically unrealistic. ${ }^{28}$ Although more direct federal intervention in local police powers could be an effective alternative, such action may be beyond the range of affairs which the federal government can constitutionally regulate.

\section{The State Response: Statutory Alternatives}

The state appears to be the only level of government holding real promise of establishing opportunities for the implementation of factorybuilt housing. At the outset, there appear three principal alternatives involving state action: (1) the model building code, (2) the mandatory building code, and (3) the factory-built housing statute.

Politically, the model code is the optimal solution at the state level. It authorizes the state to evaluate new construction techniques and materials and to incorporate the results in an optional code available to all municipalities. Yet model codes have been notoriously unsuccessful on the national level. Presently, there are in operation at least four different national uniform codes which a large number of municipalities purport to follow. ${ }^{29}$ Despite these efforts, recent studies indicate that fewer than fifteen per cent of the large municipalities have maintained modernized versions of the model code. ${ }^{30}$ The state effort in the direction of a model code appears to be little more than a duplication of preexisting national efforts with an equally unsatisfactory prospect of success. Whatever its advantages as an informational tool, the optional nature of a model code places the primary decisionmaking power in the hands of local governments. Predictably, these municipalities have been unresponsive to reform measures designed to serve statewide and national needs that may be antithetical to the felt necessities of their local constituencies. ${ }^{31}$

At the opposite end of the spectrum stands the mandatory code, a solution recommended by the National Commission on Urban Prob-

28 Recently HUD has been urged to cut back on attempts to tie low-income housing strings to water works development grants. H.R. REP. No. 91-1556, 91st Cong., 2d Sess. 7754-56 (1971).

29 A. MaNvet, supra note 9, at 11, 12.

$30 \mathrm{Id}$. at iii.

31 New York is among those states that have felt it worthwhile to maintain a model cođe. NEW York Executrve LAW \$§ 370-87. See also MrNN. STAT. ANN. \$§ 16.83-16.87 (1967); N.J. StAT. ANN. \& 13:1B-7 (1968). The model code solution is also recommended by the Advisory Commission on Intergovernmental Relations as making available the resources of the state without disturbing the traditional authority of the municipalities. ADvisonY COMOM'N ON INTERGOVERNMENTAL RELATIONS, supra note 8, at 93-95. 
lems.32 This alternative calls for the complete replacement of local codes by a state code regulating all building construction. Unquestionably, a modern statewide code would destroy the local barriers to low income housing presently created by municipal building regulations. However, proposals for such a comprehensive law can be expected to evoke determined political resistance by local interest groups. Unlike the model code, mandatory legislation challenges deeply imbedded traditions of home rule, which in some states have been accorded protection through specific constitutional guarantees. Moreover, there may be legitimate arguments for the retention of the general building code power at the local level. At present, most housing is constructed entirely at the building site. This localized nature of the building function has been the keystone of the argument that building is a purely municipal affair within the meaning of home rule constitutions. Where local sovereignty is protected by constitutional mandates, the complete removal of the code function from the municipality may prove legally impossible. Only one state has been able to enact a comprehensive mandatory building code. ${ }^{33}$ In general, centralized state control presents a long-term goal, rather than an immediate solution to problems that have already reached a critical stage.

Recently, attempts have been made to balance the political and constitutional imperatives for local building regulation against the statewide need for a broad low-cost housing market. The resulting statutes have been termed "factory-built housing" laws, and constitute a response to what the President's Task Force on Housing called "the single most important need today . . . a system of off-site certification that will (a) [provide] every reasonable encouragement to producers to use the most economical methods and materials, and (b) assure that off-site certification will be accepted locally at the construction site..$^{34}$

Factory-built housing legislation has recently been enacted in California, ${ }^{35}$ Virginia, ${ }^{36}$ Washington, ${ }^{37}$ and Ohio. ${ }^{38}$ The statutes provide for the development of state standards for factory-built housing which supersede conflicting local regulations. A specified department of the state government is vested with the responsibility to set official standards, to inspect factory-built homes, and to issue insignia of certifica-

32 DOUGLAS REPORT, supra note 2, at 269-70.

33 Conn. Gen. Stat. ANn. \$ 19-395e (Supp. 1971).

34 President's Task Force on Low Income Housing, supra note 26, at 6.

35 Cal. Health \& Safety Code ANN. \$§ 19960-94 (Deering Supp. 1970).

38 Ch. 305, [1970] Va. Acts 393.

37 Ch. 44, [1970] Wash. Laws Ist Sess. (41st Legis., 2d Ex. Sess.) 309.

38 OHo REv. CODE, ch. 3781 (1970). 
tion to complying housing units. The impact of that certification is indicated by the language of the California statute:
All factory built housing bearing an insignia of approval ... shall be deemed to comply with the requirements of all ordi- nances or regulations enacted by any city, city and county, county, or district which may be applicable to the manufac- ture of such housing. ${ }^{39}$

The statutes thus embody an attempt to isolate a category of housing according to its method of construction, and to remove from local control the regulation of that housing. Their success depends on four factors: (1) scope of coverage, (2) the certifying agency, (3) flexibility of the standards, and (4) a mechanism for interstate certification.

In scope of coverage the statutes diverge significantly. Mobile homes are included under the concept of factory-built housing in Virginia ${ }^{40}$ and specifically excluded under the Washington statute, ${ }^{41}$ while California and Ohio are silent on the question. The issue has major practical significance since mobile homes currently provide an extremely economical form of mass-produced housing. ${ }^{42}$ Their exclusion severely limits the practical impact of any statute. Factory-built housing laws could also be designed to cover new processes by which factories are erected on the construction site for the manufacture of a large number of housing units which are to comprise a single development. ${ }^{43}$ Such processes alleviate the costly diseconomies of transporting prefabricated housing over long distances. ${ }^{44}$ Despite these advantages, Virginia's definition of factory-built housing includes only buildings assembled or systems manufactured "off-site,"45 and Washington's statute deals only with a structure or room "substantially prefabricated or assembled at a place other than a building site." 46 California allows assembly on-site, but manufacture must take place off-site to be included under the statute. ${ }^{47}$ The Ohio statute is silent on the question. These diffculties in drafting appropriate coverage may be indicative of a gap

39 Cal. Health and Safety Code ANn. § 19981 (Deering Supp. 1970).

$40 \mathrm{Ch} .305, \S 12$ [1970] Va. Acts 395.

41 Ch. $44, \S \S 1(3)$ [1970] Wash. Laws 1st Ex. Sess. (41st Legis., $2 d$ Ex. Sess.) 310.

42 E. Eaves, How the Many Costs of Housing Fit Together 100-01 (1968). See also DOUGLAS REPORT, supra note 2, at 438-40.

43 See An Assembly-Line Answer to the Housing Crisis, Fordune, May 1, 1969, at 99; Will Homes Soon Be Built by a Factory That Travels? Product EngineEring, July 29, 1968, at 29. Note the suggestions for appropriate model legislation in Council of STATE GOVERNMENTS, 1971 SUgGESTEd STATE LEgisLation 55 (1970).

44 See E. EAves, supra note 42, at 99.

$45 \mathrm{Ch} .305$, § 2(3) [1970] Va. Acts 393.

46 Ch. 44, § I(3) [1970] Wash. Laws 1st Ex. Sess. (41st Legis., 2d Ex. Sess.) 310.

47 CAL. HeAlth \& SAFETy CODE ANN. \& 19971 (Deering Supp. 1970). 
between developing technology and even the most recent legislative response.

The second factor in the success of a factory-built housing statute is the existence of an appropriate regulatory agency. Since craft unions and associated industries are a major source of conservatism in building code regulation, ${ }^{48}$ an independent agency, not closely associated with industrial interests, can be expected to adopt the most progressive approach to factory-built housing standards; the agency selected should be one for which the provision of housing is a primary duty. ${ }^{49}$ More important, however, are the qualifications of the personnel who formulate the regulatory standards. Significantly, the Washington statute specifies that local government, building trades, and manufacturing interests will receive representation on its new advisory board..$^{50}$ The Galifornia statute goes so far as to mandate that of its eleven-member board, "five members shall be appointed from the legislative bodies of cities and counties." representation of private or municipal interests, but provides instead for a board of building standards composed entirely of professional experts and government employees from the several state agencies. ${ }^{52}$

The third factor, flexibility of standards, is closely tied to the second. The agency should have the statutory responsibility to adopt the most modern technology available, with the flexibility and speed demanded by the present housing shortage. Three states require the state commission to take due regard of national model codes. ${ }^{53}$ Virginia goes furthest in this regard by providing for annual review of its code in relation to the developing housing needs of the state. ${ }^{54}$ Ohio, on the other hand, provides no statutory guidance for modification of its code.

48 See notes 11-19 supra.

40 This appears to be the situation in California, where the agency is the Department of Housing and Community Development. CAs. Health \& SAFETY Code ANn. \& 19966 (Deering Supp. 1970). However, in the other states the selected agency does not appear to have a similarly specialized focus. In Virginia, the certifying agency is the State Corporation Commission, Ch. 305, § 2(2) [1970] Va. Acts 393; in Washington, the Department of Labor and Industries, Ch. 44, \& I(1) [1970] Wash. Laws 1st Ex. Sess. (4Ist Legis., 2d Ex. Sess.) 310; and in Ohio, a board of building standards within the Department of Industrial Relations, Ohio Rev. Code ch. 3781.07 (1970).

50 Ch. 44, § 6 [1970] Wash. Laws Ist Ex. Sess. (41st Legis., 2d Ex. Sess.) 311.

61 Car. Health \& SAFEty Code ANN. § 19994 (Deering Supp. 1970).

52 OHIO REv. CODE ch. 3781.07 (1970). The Virginia statute makes no provision for any special group below the State Corporation Commission, although it does provide for public hearings after notification to all municipalities. Ch. 305, \$ 5 [1970] Va. Acts 394.

53 Cal. Health \& SAFETy Code ANN. \$ 19990 (Deering Supp. 1970); Ch. 305, \& 4 [1970] Va. Acts 394; Ch. 44 \& 7 [1970] Wash. Laws 1st Ex. Sess. (41st Legis., 2d Ex. Sess.) 312.

54 Ch. $305, \S 6[1970]$ Va. Acts 395 . 
A mechanism for interstate certification, the fourth factor, is especially important to the success of factory-built housing. Any significant reduction in housing costs can be achieved only by the creation of a nationwide housing market responding to a multi-state reform in housing code provisions. ${ }^{55}$ The state factory-built housing law can provide the means to effectuate interstate cooperation in the realization of cost reductions through mass production. However, only Washington's statute establishes a framework for such a development:

If the director of the department determines that the standards for factory built housing prescribed by statute, rule or regulation of another state are at least equal to the regulations provided under this act, and that such standards are actually enforced by such other state, he may provide by regulation that factory built housing approved by such other state shall be deemed to have been approved by the department. ${ }^{56}$

While none of the four statutes presently enacted incorporates all four above mentioned factors, taken together they illustrate the most promising route to the successful development of a factory-built housing market on a nationwide scale. Moreover, the statutes embody a minimal governmental function-the state acts simply as an enlightened licensee of private entrepreneurial activity. As such it steers clear of the government-as-developer role, ${ }^{57}$ an alternative which, because it demands extraordinary funding and dramatic extensions of state power, has severe political limitations..$^{58}$ Finally, the factory-built housing law avoids the massive confrontation with home rule tradition engendered by an attempt to remove the entire building regulation function from local control by a mandatory code.

\section{Obstacles To Implementation}

The factory-built housing statute holds the promise of a significant alteration in the pattern of American housing development. However,

55 Strong emphasis is placed on the importance of a nationwide certification program in PRESIDENT'S TASK Force on Low INCOME Housing, supra note 26, at 6.

56 Ch. 44, \& 8 [1970] Wash. Laws 1st Ex. Sess. (41st Legis., 2d Ex. Sess.) 313.

57 The paramount example is the New York State Urban Development Corporation. Ch. 173-77, [1968] N.Y. Sess. Laws 227. A similar alternative is the establishment of a state housing development commission. See Salsick, Housing and the States, 2 UrBaN LAW. 40 , 58-60 (1970).

58 Reilly \& Schulman, The State Urban Development Corporation: New York's Innovation, 1 URBAN LAw. 129, 145-46 (1969). Moreover, the Kerner Commission concludes that only if private enterprise becomes a major factor in the low-cost housing field will housing units constructed meet housing needs. National Advisory COMM'N ON Crvil Disoroers, supra note 3 , at 476 . 
such a statute is faced with three obstacles: (1) possible invalidation under home rule constitutions, (2) impact dilution due to suburban zoning ordinances, and (3) substitution of the union contract as the functional equivalent of the municipal building code.

\section{A. Constitutional Fome Rule}

While the limited scope of the factory-built housing statute avoids the major legal conflicts of a mandatory code, the statute's constitutionality in some home rule states is still questionable. Home rule involves a legislative or constitutional grant of power to localities to adopt a government charter for the control of local affairs. ${ }^{59}$ About half of the states provide home rule guarantees in their state constitutions. ${ }^{60}$ Usually, the wording is vague; it may, for example, grant local control over "municipal affairs." 61 Consequently, where state and local legislation conflict, the courts have been required to play a major policy-making role in determining which shall yield. ${ }^{62}$

In most instances the courts are strong adherents of legislative supremacy, ${ }^{63}$ so that unless preemption by the state is not explicit ${ }^{64}$ the home rule doctrine will seldom pose a problem. Thus, in two of the three factory-built housing states with home rule, ${ }^{65}$ a legislative intent to supersede local building code regulations will usually be determinative in any court challenge. The language of the Ohio Supreme Court is characteristic: "Surely, statutory enactments representing the general exercise of police power by the state prevail over police and similar regulations adopted in the exercise by a municipality of the powers of local self-government."66

69 F. Michelman \& T. SANDALOW, Materials on GoVERNMENT IN URbaN AREAS 302 (1970). Bo C. RaYNe, Municipal LAW $\$ 4.3$ (1957); 1 E. MGQuillan, Municipal Corporations § 3.21 (3d ed. 1949); Sandalow, The Limits Of Municipal Power Under Home Rule: A Role for the Courts, 48 Mins. L. REv. 643, 645 (1964).

61 Sandalow, supra note 60 , at 660 .

62 Allocation of responsibilities for effective governing is a matter that, in comparison with the legislature, the judiciary may be ill-equipped to decide. Note, Conflicts Between State and Municipal Ordinances, 72 HARv. L. REv. 737, 742 (1959).

63 Id. at 742. Both the political relationship of the parties and basic principles of democratic politics argue for a legislative determination of what constitutes "municipal affairs." Compare F. Michedman \& T. SANDALOW, supra note 59, at 363-64, with Hanson, Toward a New Urban Democracy: Metropolitan Consolidation and Decentralization, 58 Gro. L.J. 863, 888 (1907).

84 For the difficulties of finding preemption in the face of vague legislative intent, see generally Feiler, Conflict Between State and Local Enactments-The Doctrine of Implied Preemption, 2 URBAN LAW. 398 (1970).

65 The applicable state constitutions with home rule provisions are CAL. Const. art. XI, \& 6; OHIo Consr. art. XVIII, \& 7; and WASH. ConsT. art. XI, § 10.

66 State v. Dayton Power \& Light Co., 10 Ohio St. 2d 14, 17, 225 N.E.2d 230, 233 (1967). See also Cincinnati \& Suburban Bell Tel. Co. v. City of Cincinnati, 34 Ohio Op. 2d 
California, however, is representative of those states in which the courts have jealously guarded constitutional home rule in its most doctrinaire form. ${ }^{67}$ The Galifornia courts separate the question of constitutionality (which arises when the state attempts to legislate on a municipal affair) from the issue of preemption (in which the municipality passes an ordinance regulating some matter on which the legislature has previously enacted a statute. ${ }^{68}$ In the former, the test effectively favors state action by declaring that only "exclusive municipal concerns" will preclude state legislation. ${ }^{69}$ In contrast, a twofold test is applied to the preemption question, and the standards adopted appear to favor municipal ordinances. First, the state must show that the subject is a state concern rather than a purely municipal interest..$^{70}$ Second, even if the subject is a statewide concern, the municipality is not preempted unless that is shown to be the intent of the legislature. ${ }^{71}$

Since the legislative intent in enacting the factory-built housing statutes clearly was to preempt the area, ${ }^{72}$ the essential question to be determined in both instances is whether the regulation of factory-built housing is to be considered a "municipal affair." In California, this issue has been reserved to the courts. As stated in Bishop v. Gity of San Jose, ${ }^{73}$ " $[\mathrm{T}]$ he legislature is empowered neither to determine what constitutes a municipal affair nor to change such an affair into a matter of statewide concern." 74 The courts have traditionally held that building codes, like zoning, are a municipal matter appropriate for the valid

445, 215 N.E.2d 631 (1964). A similar approach is followed in Washington. See State v. Ensminger, - Wash. 2d -, 463 P.2d 612 (1970); City of Spokane v. Carison, 73 Wash. 2d 76, 436 P.2d 454 (1968); State v. Lundquist, 60 Wash. 2d 397, 374 P.2d 246 (1962). "[T]n Washington a statute always supersedes a conflicting ordinance." Trautman, Legislative Control of Municipal Corporations in Washington, 38 WASFr. L. REv. 743, 778 (1968). In Virginia, where there is no home rule, "an ordinance in conflict with state law of general character and statewide application is universally held to be invalid." Hanbury v. Committee, 203 Va. 182, 185, 122 S.E.2d 911, 913 (1961).

67 For a characteristic example of the operation of California law in this field, see Note, Income Taxation and Preemption, 17 HAstrngs L.J. 635 (1966).

68 Professional Fire Fighters, Inc. v. City of Los Angeles, 60 Cal. 2d 276, 292, 384 P.2d $158,168,32$ Cal. Rptr. 830, 840 (1963), cited with approval in Baron v. City of Los Angeles, 2 Cal. 3d 535, 537, 469 P.2d 353, 355, 86 Cal. Rptr. 673, 675 (1970).

69 Id.

$70 \mathrm{Id}$.

71 Galvan v. Superior Court, 70 Cal. 2d 851, 452 P.2d 930, 76 Cal. Rptr. 642 (1969); Alta-Dena Dairy v. County of San Diego, 271 Cal. App. 2d 66, 76 Cal. Rptr. 510 (1969).

72 See text at note 39.

73 Bishop v. San Jose, I Cal. 3d 56, 460 P.2d 137, 81 Cal. Rptr. 465 (1969).

74 Id. at $63,490 \mathrm{P} 2 \mathrm{~d}$ at $141,81 \mathrm{Cal}$. Rptr. at 469 . There has been considerable uncertainty as to the effect of a legislative definition of municipal affairs. Compare Note, Municipal Corporations, 53 CAL. L. REv. 902 (1965) with Note, 50 CAL. L. REV. 740 (1962). 
exercise of local police power. ${ }^{75}$ Yet the courts have recognized the dynamic nature of the "municipal affair" concept:

$[T]$ he constitutional concept of municipal affairs changes with the changing conditions on which it is to operate. What may at one time have been a matter of local concern, may at a later time become a matter of state concern controlled by the general laws of the state. ${ }^{76}$

Today, as in the past, the large volume of home building takes place on-site with few or no manufactured parts. As a local process, it fits easily into traditional geographic concepts of what constitutes a municipal concern. However, as population and community interdependence increase, the simplistic geographic model appears progressively inadequate. Land use requirements can have a major impact beyond local borders, ${ }^{77}$ trapping large numbers of the population within narrow urban confines. ${ }^{78}$ Significant economic effects can result from the ability of the municipality to constrict the growth of a nationwide industry by what amounts to local trade barriers. ${ }^{79}$ Closely tied to the concept of extraterritorial impact is the failure of the local political process to represent those groups most directly affected by the exclusionary consequences of regulatory policy. ${ }^{80}$

While the argument springing from extraterritorial impact might just as easily apply to all kinds of housing, factory-built housing lays

75 See Lindell Co. v. Board of Permit Appeals, 23 Cal. 2d 303, 144 P.2d 4 (1943) (building permits); Fletcher v. Porter, 203 Cal. App. 2d 313, 21 Cal. Rptr. 452 (1962) (zoning). See also 2 E. McQuillan, supra note 60 , at $\$ \S 4.112 \mathrm{~A}, 4.91$.

76 Bishop v. San Jose, 1 Cal. 3d 56, 63, 460 P.2d 137, 141, 81 Cal. Rptr. 465, 469 (1969).

77 "Recent reevaluation of minicipal home rule is primarily a result of increasing awareness that the powers exercised by municipal governments wholly within their boundaries may have consequences in surrounding areas." Sandalow, supra note 60, at 700. See also Report of the California Commission On Preemption, 2 URBAN LAW ANNuAL 130 (1969), concluding that the need for statewide uniformity in regulation becomes greater than the need for the city to impose its will when "local regulation would have significant adverse effects on the movement of persons or goods within the state." $Y d$. at 138.

78 See Sager, Tight Little Islands of Exclusionary Zoning: Equal Protection and the Indigent, 21 STAN. L. REv. 767, 781 (1969); Sandalow, supra note 60, at 707.

79 Note, Building Codes: Reducing Diversity and Facilitating the Amending Process, 5 HARV. J. LEGIS. 587, 596 (1968).

80 Sandalow, supra note 60, at 710-11. "A use of governmental power which threatens ... established state policies might not be deemed a 'local' or 'municipal' affair for the same reason that 'municipal' regulations with too great an extraterritorial impact are not considered to be 'local' . . . the inadequacy of the political process at the local level to cope with such problems." Id. at 717. At least one author sees the home rule struggle as an attempt to prevent municipal Balkanization in areas of special concern. "Only a standard of statewide uniformity can fully implement the values of free speech and due process, the rights of privacy, and other fundamental values." Blease, Civil Liberties and the California Law of Preemption, 17 Hastancs L.J. 517, 569 (1966). 
claim to an extralocal category on an independent ground. Unlike other kinds of housing, the factory-built process takes place off-site and even out-of-state. This form of construction, even under traditional rules based on the location of the activity, is not a purely municipal concern.

A further ground for the recognition of mass-produced housing as a statewide concern is the inability of local procedures to provide adequate protection against defects in safety. In its modern context, housing has become a "scientific" area which cannot adequately be administered by local authorities who lack the requisite expertise to supervise health and safety regulation. As stated in the Virginia code:

Industrialized building units, . . because of the manner of their construction, assembly and use and that of their systems components . . . having concealed vital parts, may present hazards to the health .... [T] here is also the possibility of defects not readily ascertainable when inspected by purchasers, users, or by local building official. ${ }^{81}$

Recent studies for the National Commission on Urban Problems indicate that most of the regulating governments are too small to retain full-time employees for such work..$^{82}$ Moreover, even in those situations in which people are employed on a full-time basis, salaries are too low to attract those who are well trained in professional or technical skills. ${ }^{83}$ The Advisory Commission on Intergovernmental Relations concludes:

The qualifications possessed by many building officials are inadequate to properly advise on the administration of modern performance-type building codes. While it is possible that these officials can deal competently with the ordinary run of traditional buildings, the advances expected in building technology will demand a more expert knowledge of a wide variety of building practices and materials. ${ }^{84}$

When local processes are inadequate to protect health and safety, and would in any case be wasteful and duplicative with respect to massproduced housing, the matter should be treated as a statewide concern.

The isolation of a particular kind of building for special treatment is not foreign to the law of California or indeed of most other states. For example, in Hall $v$. Taft, ${ }_{9}^{85}$ the Supreme Court of California held

81 Ch. 305, \& 3 [1970] Va. Acts 394 (emphasis added).

82 A. MANVEL, supra note 9 , at 2.

83 Id.

84 ADVISORX COMM'N ON INTERGOVERNMENTAL RELATIONs, supra note 8, at 99.

8547 Cal. 2d 177, 302 P.2d 574 (1956). 
that school construction could not be controlled by municipal building regulations where the state legislature had established regulatory agencies and adopted standards for such buildings. ${ }^{86}$ Moreover, the courts of a majority of jurisdictions have, under the doctrine of sovereign immunity, exempted state agencies from local building regulation. 87

While the factory-built housing law represents an infringement on traditional areas of local control, little justification exists for invalidation in light of the widespread social and economic effects, the nonlocal construction process, and the necessity of expertise in creating and implementing health and safety standards. Activities once clearly local now take on larger proportions. This transformation raises the fundamental question: Can the home rule concept maintain its integrity and at the same time respond flexibly to the fluid concept of "municipal affairs"? In view of the growing pressures to strip municipalities of all control of land use, it may be that the survival of home rule in any form depends on the kind of compromise embodied in the factory-built housing law.

\section{B. Zoning}

Although the factory-built housing statutes provide a possible solution to the problem of exclusionary building codes, they are careful to protect a classic alternative device. ${ }^{88}$ Exclusionary zoning can be effective in limiting any breakthrough in mass-produced housing by barring those low-income groups among whom the demand for such housing is greatest. It is on zoning, however, that the statutes of California, Virginia, and Washington appear to have achieved absolute agreement. In the language of the California statute:

Local use zone requirements, local fire zones, building setback, side and rear yard requirements, site development and property line requirements, as well as review and regulation of architectural and aesthetic requirements, are hereby specifically and entirely reserved to local jurisdictions notwithstanding any requirement of this part..$^{89}$

While legislative silence on the issue of zoning would not automat-

$86 I d$. at 188,302 P.2d at 581 (1956).

87 Note, Municipal Power To Regulate Building Construction and Local Land Use by Other State Agencies, 49 MinN. L. Rev. 284, 286 (1964).

88 "The most effective subterfuge for segregating disadvantaged minority groups is the device of economically discriminating zoning restrictions." Note, supra note 17, at 128.

89 Cal. Health \& Safety Code ANN. § 19993 (Deering Supp. 1970). See also Ch. 305, $\S 12$ [1970] Va. Acts 395; Ch. 44, § 3 [1970] Wash. Laws Ist Ex. Sess. (4Ist Legis., 2d Ex. Sess.) 311. 
ically have invalidated local land use requirements, it could have set the stage for a judicial challenge to zoning practices that contravened the broad policy set forth in both the California and Virginia statutes. As the former states:

The legislature further finds and declares . . . its intention to encourage the reduction of housing construction costs and to make home ownership more feasible for residents of this state. ${ }^{90}$

With a clearly enunciated policy of removing barriers to low-cost housing, sympathetic state courts could have been expected to frown upon zoning practices which vitiated the legislative intent. The major paradox of the factory-built housing statutes is that they invite, in explicit terms, what the courts probably would have found to be antithetical to the statutory scheme-the construction of zoning barriers to replace those previously provided by building codes.

The express statutory reservation of the zoning power to local governments calls into question the practical significance of the factorybuilt housing laws. Undoubtedly, when exclusion is the objective, no instrument is more effective than the zoning power. ${ }^{91}$ Yet to conclude that nothing has been achieved by factory-built housing laws may be to ignore both the complexities of the problem and the significant case law developments that have invited increased judicial scrutiny of the zoning power.

While the suburban communities have directed their antipathy toward low-cost housing, they have simultaneously shown a greater willingness to accept middle class inflows of both whites and blacks. ${ }^{22}$ One of the characteristics of a building code is that it increases the cost of housing at all levels regardless of the group that was intended to be excluded. If the building codes are eliminated, suburban communities must take new initiatives to effectuate a policy that selectively excludes certain social groups. In this context, there is little reason to

90 Car. Health \& Safety Code § 19961. See also Ch. 305, § 3 [1970] Va. Acts 394.

91 See note 88 supra. This is not to suggest that zoning is the only weapon of local control still available. Delays and costs may be imposed on a developer by local regulation of access to sewers, water, and roads as well as by property valuation and requirements of licenses and construction bonds. See Fischer, supra note 8, at 164. Moreover, where the developer plans on an economically integrated housing development (consisting of low-income manufactured homes and high-income conventional housing), the conventional housing portion of his construction will still be under local control. A home producer who plans a large development over a ten- or fifteen-year period may be unwilling to sacrifice the goodwill and cooperation of local authorities by taking advantage of unpopular state-controlled factory-built housing options.

82 Fisher, supra note 8, at 172 . 
believe that factory-built, middle-income housing will be confronted with the same zoning obstructions as will low-income developments. While failing to maximize economic integration, the statutes thus at least could be instrumental in alleviating the large portion of the housing shortage that extends to the middle-income group. Moreover, any significant movement of middle-income families may be expected to create vacancies for low-income families as part of the so-called "filtering down" process. $^{93}$

The systematic exclusion of low-income housing, on the other hand, probably will not be overcome without further action by the courts. The advantage gained by the factory-built housing law is that it removes the barrier least susceptible to judicial erosion. The traditional zoning weapons, including such mainstays as minimum lot and floor sizes, and aesthetic requirements, have been the object of increasing criticism. $^{94}$ And although judicial challenges have so far produced uneven results, ${ }^{95}$ some commentators maintain that the courts will eventually place sharp restrictions on the use of the zoning power. ${ }^{96}$ At the same time, the courts are more inclined to leave building codes

93 F. Kristof, Urban Housing Needs Through the 1980's: AN ANalysis and Projection 69 (1968). "Most of the gains in Negro housing have occurred through the turnover which occurs as part of the 'filtering down' process-as the white middle class moves out, the units it leaves are occupied by Negroes. Many of the units are very old. Without proper maintenance, they soon become dilapidated, so that the improvement in housing resulting from the filtering-down process is only temporary." NATIONAL ADVISORY COMDM'N ON CrviL DIsORDERs, supra note 3, at 473.

04 See generally Sager, supra note 78. Michelman suggests that exclusionary municipal regulation may be attacked under three theories: "1) by the same style equal protection argument which ... may also yield a constitutional right to be housed; 2) by arguments focused on the political or participatory claims of those who must suffer the consequences ... though afforded no voice in the fashioning of exclusive regulations, or 3) appeals to the conflict between such regulations and federal policies calling for provision of subsidized housing outside areas of racial concentration." Michelman, The Advent of a Right to Housing: A Current Appraisal, 5 HARv. Crv. Richts-Crv. LIB. L. REv. 207, 216 (1970).

95 See Sager, supra note 78, at 782-83; Note, supra note 17, at 128-29.

96 See Michelman, supra note 94, at 216-17. As late as 1969, Sager's assessment was that "[e]qual access to housing is regarded by the Court as a matter of the most serious social and constitutional concern. . . . While it has been manifest in the context of racial discrimination, there is reason to expect it will be evoked on behalf of the indigent as well." Sager, supra note 78, at 790. On the other hand, the Court's recent decision on the California public housing referendum law was an implicit refusal to apply fourteenth amendment protections to cases of economic discrimination. James v. Valtierra, $91 \mathrm{~S}$. Ct. 1331 (1971). Nevertheless, it is doubtful whether that decision, supported by only a narrow majority, has finally put to rest the question of equal access to housing for all income groups. Moreover, lawyers are arguing persuasively that because a large proportion of blacks have low incomes, racial implications are inherently linked to the economic issue, and that economic discrimination consequently becomes an appropriate basis of fourteenth amendment relief. See The Wall Street Journal, April 27, 1971, at 2, col. 4 (Midwest ed.). 
untouched. Courts avoid making judgments about "technical" matters related to engineering and physics, which are far from their own area of competence. ${ }^{97}$ Nor are they willing to sacrifice safety considerations, even in the face of the most pressing social needs. Thus, where the legislature has acted to limit the effect of building regulations, the path is cleared for judicial initiatives to restrict zoning practices and to open the suburbs to low-cost housing for all economic groups.

Finally, a failure to realize statutory goals due to local zoning practices may quickly give rise to statewide zoning legislation to provide selective protection for factory-built housing. The most recent proposals of the Council of State Governments suggests exactly this kind of legislation.98 Moreover, limited state zoning regulations have already been adopted in Massachusetts in connection with state-approved nonprofit efforts to erect low-cost housing. ${ }^{99}$ As Michelman notes, "[A] claim not to have housing choice restricted on account of one's socioeconomic status as a practical matter entails a claim to be free of unreasonable land use restrictions; it calls for legal limitations on cost

97 See K.C. Davis, 4 Administrative Law Treatise $\S 30.09$, at 240 (1958). Professor Davis analyzes the factors which guide the exercise of judicial discretion in choosing either to substitute judgment or to use the rational basis test in reviewing administrative action. "Among these factors the one that stands out above all others is the comparative qualification of the agency and of the court to decide the particular issue. Variation in intensiveness of review in accordance with comparative qualifications is so natural as to be inevitable whatever the theory." Id. at 241. "In some cases, of course, the specialization of the agency or its staff is so clear as almost to compel use of the rational basis test. When problems 'touch matters of geography and geology and physics and engineering; hardly surprising is the Supreme Court's action in announcing that 'Plainly these are not issues for our arbitrament.... " Id. at 243, quoting Railroad Comm'n v. Rowan, Nichols Oil Co., 310 U.S. 573 (1940).

98 Council of State Governments, stcpra note 3, at $58 \mathrm{n} .2$. Clearly, a nationwide breakthrough in low-cost housing may be dependent on the willingness of a large number of states to adopt effective legislation. Yet the brunt of the housing crisis falls on the cities, and the state governments have traditionally been indifferent to the wide range of urban problems. Coleman, Making Our Federal System Work: $A$ Challenge for the 70's, 1 URBAN LAw. 302, 304 (1970). Moreover, the same opposition can be expected from the craft unions in the statehouse as appeared at the local level. On the positive side, there is evidence that reapportionment may have altered the traditional rural-urban balance, even though seniority procedures may delay its impact. See generally Hawkins \& Whelchel, Reapportionment and Urban Representation in Legislative Influence Positions: The Case of Georgia, 3 URBan AFFaIRs Q. 69 (1968). In addition, while the housing shortage is most acute in the city, the extent of the demand reaches deep into suburban communities as well. "The stereotype of the wealthy suburb is misleading." DovgLAs REPORT, supra note 2, at 74. Finally, the new study by the Citizens Conference on State Legislatures, while critical of the limited input resources available to legislators, nevertheless admits to a general improvement in the quality of state lawmaking bodies. See TIME, Feb. 15, 1971, at 16. With four states passing factory-built housing laws within one year, it may not be unrealistic to expect continued positive development with its origins in the state capitols.

99 Ch. 40-B, § 21-23 [1969] Mass. Gen. Laws. See Recent Cases, 2 Urban LAw 255, 258 (1970). 
inflating municipal regulatory powers. Such limitations are plainly in the offing." 100

\section{The Union Contract}

Should the craft unions fail to prevent the passage of factory-built housing statutes, it is reasonable to expect attempts to incorporate the substance of the traditional building code into their construction contracts. The Supreme Court decision in National Woodwork Manufacturers Association v. NLRB ${ }^{101}$ appears to legalize union efforts contractually to protect members from job loss due to "onrushing technological change."102 The impact of the decision is to allow the unions both to restrict widespread use of prefabrication through building contracts, and to cast the determinative vote as to the supply of housing and its costs. ${ }^{103}$

The right of the unions to bargain so as to restrict materials and processes is especially significant when the weakness of the employer contractors is juxtaposed with the unified economic power of the unions. ${ }^{104}$ However, union opposition to prefabrication may be misplaced. Selling more homes at lower prices could provide a stable

100 Michelman, supra note 94, at 216. Recently, the American Law Institute gave tenta. tive approval to the Model LaNd DevelopMent Code (Tent. Draft No. 3, 1971). Article 7 of that draft sets up a device for limited state government interference with local zoning in matters of state interest. Developments may be matters of statewide concern (1) because of natural resources or previous development, as in the case of new towns, id. at \$ 7-201; (2) because of their very nature, including developments substantially subsidized by state and federal agencies, id. at $\S 7-301$; or (3) because of their size, for example, a huge housing development, $i d$. at $\$ 7-401$. While the initial decision on these matters is made by the local land development agency, standards are set up which insure that the state interest is considered, and the local decision is subject to a right of appeal to a state board.

This model legislation may become especially important in light of legislation currently proposed by the Nixon Administration which would require states to maintain a system by which local land use regulation could be superseded. S. 992, 92d Cong., 1st Sess. (1971).

101386 U.S. 612 (1967). The Court upheld a union agreement under which union members were excused from handling preassembled door units. The contract was challenged under $\S 8(e)$ of the National Labor Relations Act, 29 U.S.C. 158(e) (1964): "It shall be an unfair labor practice for any labor organization and any employer to enter into any contract . . . whereby such employer ceases . . . or agrees to cease . . . handling, using ... or otherwise dealing in any of the products of any other employer ... and any contract .. . containing such an agreement shall be to such extent unenforcible [sic] and void." Nevertheless, the Court held that $\S 8(\mathrm{e})$ does not prohibit primary agreements, and that exclusion of products is a legitimate subject of bargaining where such products threaten job security.

102386 U.S. at 640.

103 See generally Petro, Unions, Housing Costs and the National Labor Policy, 32 LAw \& CONTEMP. Prob. 319 (1967); Note, Union Restrictions on the Use of Prefabrication in the Housing Industry, 55 IowA L. REv. 270 (1969).

104 Note, supra note 103 , at 278. 
labor demand.105 While skilled wages may be expected to decline in the face of mass production methods, the worker's annual income may remain the same due to the more regular work schedule. ${ }^{108}$ As the Douglas Commission concluded, "[M]any of the onerous practices that seem insoluble in the framework of widely fluctuating employment and construction patterns could more readily be resolved if the construction industry were expanded and stabilized." 107 Such a transition, however, cannot be made without sacrificing the interests of some. Until the craft unions become convinced of the long-run potential of the mass production market, the union contract will remain a substantial limitation on the factory-built housing statute.

\section{Conclusion}

The factory-built housing statute provides unique opportunities for state governments to shape a more productive and equitable pattern of housing development. The impact of these statutes will be measured by the extent to which state legislators can deal effectively with groups having a vested interest in the maintenance of an archaic construction process. However, the difficult issues of home rule, zoning, and the union contract have yet to be squarely faced. Whether in the statehouse or in the courtroom, it is the resolution of these issues that will determine whether the full promise of factory-built housing statutes will in fact be realized.

105 Id. at 285.

$106 I d$. at 286 .

107 Douglas RePorT, supra note 2, at 465. 